\title{
The effect of design of restaurant on customer behavioral intentions
}

\author{
Nawras M. Nusairat ${ }^{a *}$, Qais Hammouri ${ }^{\mathrm{b}}$, Hamad Al-Ghadir ${ }^{\mathrm{c}}$, Alaeddin Mohammad Khalaf \\ Ahmad $^{\mathrm{d}}$ and Mohammad Al Haj Eid ${ }^{\mathrm{e}}$
}

${ }^{a}$ Assistant professor of Marketing and Consumer Behaviour, Applied Science Private University, Amman, Jordan

${ }^{b}$ Department of Management Information System, Applied Science Private University, Amman, Jordan

'Professor of Marketing, Applied Science Private University, Amman, Jordan

${ }^{d}$ Professor of Marketing, Princess Sumaya University for Technology, Amman, Jordan

${ }^{d}$ Marketing Department, University of Otago, Dunedin, New Zealand

\section{H R O N I C L E \\ A B S T R A C T}

Article history:

Received: December 28, 2019

Received in revised format:

January 302020

Accepted: February 19, 2020

Available online:

February 19, 2020

Keywords:

Cognitive-affective model

Stimulus-organism-response

Restaurant design

Behavioural intentions
This study investigates the mechanism by which customers' affective and cognitive states drive their behavioural intentions towards upscale restaurants. With stimulus-organism-response (SOR) theory as a backbone, two competing mediation scenarios; one-step versus two-step mediation are examined. A dataset of 425 conveniently selected valid responses was used to test the models. Structural equation modelling shows that customer behavioural intentions were better explained by a cognitive-affective mediated model than by one-step mediated model. The results of hypotheses testing reveal the significance of restaurant design in enrichening customers' cognitive experience, thus, eliciting their affective states, which ultimately affect their behavioural intentions. This paper shows the applicability of the cognitive theory of emotions in explaining restaurant design-customer behavioural intentions relationship. The results also provide insights for restaurant operators on how the design characteristics of their restaurants can be best utilised to encourage positive customer responses. Discussion, conclusion and future work are also provided.

\section{Introduction}

The term "Servicescape" as first introduced by Bitner (1992) describes the physical environment, where the service is provided. Typically, in a servicescape, both customers and employees are exposed to numerus cues and do response in affective and cognitive manners. Since the first time the "Servicescape" term has been brought to service and hospitality literature, increasing research efforts devoted to examine the influence of various factors of the service environment on customers' responses (Wakefield \& Blodgett, 1996; Kim \& Moon, 2009; De Nisco \& Warnaby, 2013; Meng \& Choi, 2017; Dedeoglu et al., 2018; Park et al., 2019). Marketing atmospherics and environmental psychology literatures substantially acknowledge the role of servicescapes in driving customers' responses. In this extent, the stimulus-organism-response (SOR) model of Mehrabian and Russell (1974) has inspired much of the previous empirical studies. The SOR model has been largely used to capture the interrelationship among the physical environment $(\mathrm{S})$ customer affective and cognitive states $(\mathrm{O})$ and behavioural responses (R) in different business contexts (Donovan, et al., 1994; Chang et al., 2011; Kumar \& Kim., 2014; Nusairat et al., 2017; Ortegón \& Royo, 2019). Nevertheless, in some cases, the model shows a deficiency on linking store environment to customer behavioural responses (e.g. Chebat \& Michon, 2003). Other empirical studies revealed challenging findings, where customers' cognition was found to precede customers' affections in carrying the impact of environmental factors on customer

* Corresponding author. Tel.: +64 2102971940

E-mail address: mohammad.alhajeid@postgrad.otago.ac.nz (M. Al Haj Eid) 
behaviour in different retail and service contexts (Kivela et al., 1999; Dennis et al., 2012; Kumar \& Kim, 2014). With this knowledge gap in mind and motivated by the absence of empirical studies on customer restaurant behaviour in Jordan, the current research seeks to examine the role of restaurant design in shaping restaurant customer behavioural intentions through assessing two different scenarios of mediation for customers' affective and cognitive states in the context of upscale restaurants.

\section{Research significance}

Understanding the maze of the mediation suggested by the research models of this study (e.g. one-step or sequential) is insightful for theory and practice. Theoretically; this paper is expected to generate a distinct understanding on the mediating effect of both affective and cognitive states on the relationship between restaurant design and customer behavioural intentions. That is, the study utilizes a broader perspective, whereby the cognitive theory of emotion or cognition-emotion approach is integrated with the M-R model to create two alternative cases of mediation. A simultaneous empirical testing for the resulting competing cases of mediation (i.e. one-step and two-step) for the first time contributes to the novelty of this paper. In addition to that, design factors are explored in this study as a multidimensional factor rather than a certain specific dimension such as colour and layout as reported by the most of previous studies (e.g. Githiri, 2016; Jain et al., 2014; Ryu \& Han, 2011; Tantanatewin \& Inkarojrit, 2018). Furthermore, the research findings are expected to provide a theoretical foundation that explains how the affective and cognitive states influence customers' intentions specifically in restaurant settings. Empirically, the research findings are expected to be insightful for practitioners through depicting the significance of the design factors in shaping customer intention. Furthermore, understanding how the maze of mediation works can be helpful in leveraging the influence of design characteristics on customer intentions.

\section{Theoretical framework and hypotheses development}

Much of previous research approved that the Mehrabian and Russell's model is considered as one of the best models to understand the impact of the business environment on customer intentions in different retail and services contexts (Chang et al., 2011; Kalra et al., 2016; Vieira, 2013). The dominate idea of such stream of research is that the features of retail and/or service environments $(\mathrm{S})$ affect customer internal states including emotion and/or cognition $(\mathrm{O})$, which in turn leads to specific behavioural responses $(\mathrm{R})$. The emotional states are derived from the environmental psychology model of M-R. Emotion (Pleasure \& Arousal) and cognition is proposed to operate simultaneously as organism mediating variables in the S-O-R series. Based on that, a restaurant's design directly affects customer affective states and the perceived quality of restaurant servicescape, which, in turn, drive customer behavioural intention.

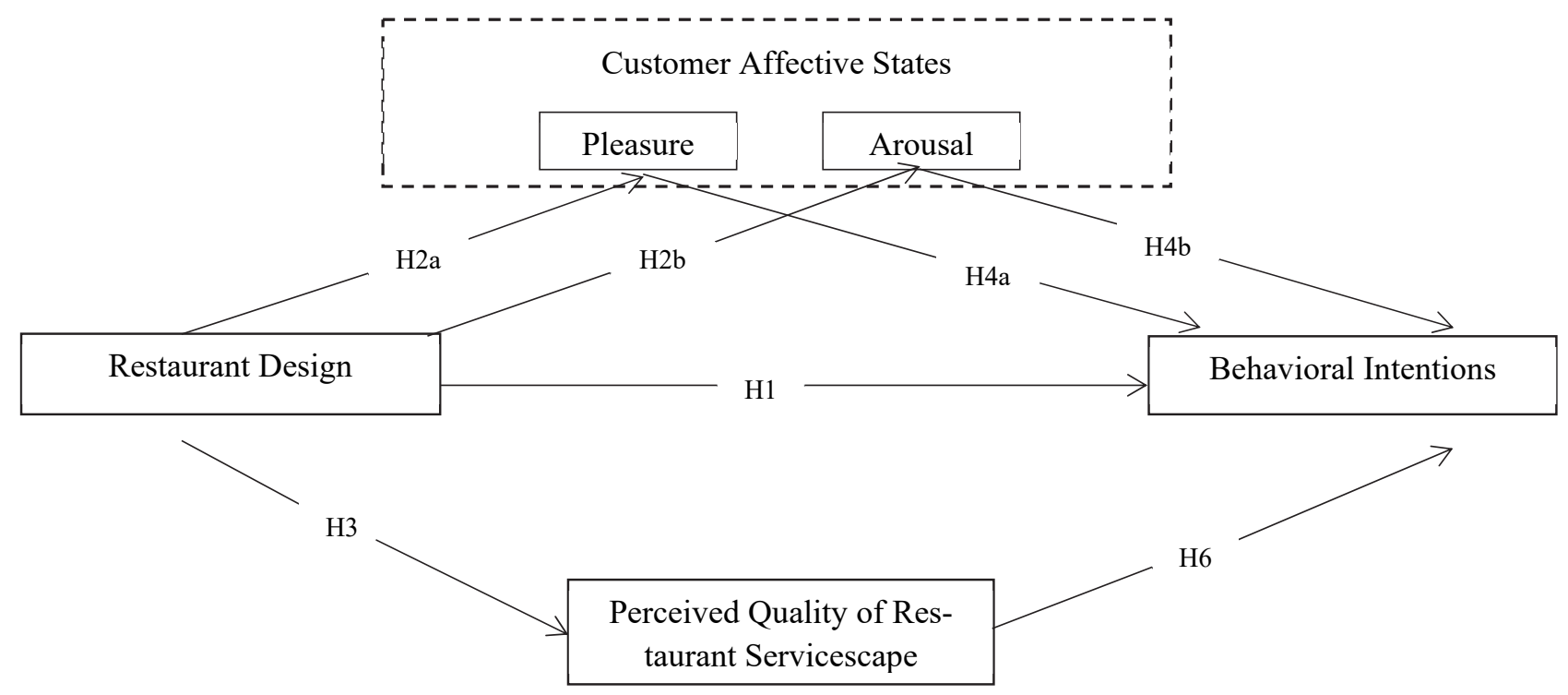

Fig. 1. One-step Parallel Mediation Model

On the other hand, and based on the cognitive theory of emotions (Lazarus, 1991) the effect follows a cognitive-affective sequence of mediation, whereby the cognitive evaluation of the restaurant environment is a critical antecedent before affective states emerge (Fig. 2). That is, restaurant design factors affect customer affective states indirectly through the perceived quality of servicescape and this ultimately leads to customer behavioural intention. According to Martín-Ruiz et al. (2012) servicescape is believed to be of the most important factors that may contribute to enrich customer contextual experience and to encourage more positive responses. In this extent, Wakefield and Blodgett (1996) declared that servicescape influences perceived quality, which result in more satisfaction. To explore the interaction between the environment and customer responses 
to environmental stimuli, M-R model founded by Mehrabian and Russell (1974) is considered as one of the robust models utilized to evaluate the influence of atmospheric on consumer behaviour in in different consumption areas (Ali \& Amin, 2014; Heung \& Gu, 2012; Ryu \& Han, 2011; Tantanatewin \& Inkarojrit, 2018). According to S-O-R model, design factor is considered as a stimulus influencing individual's emotions. Baker (1986) originated the term "design factors" to describe the visual elements that are visible to customers involving functional elements such as store layout and displays and aesthetic ones such as colour and décor, which can influence an individual's experience. Design factors such as layout have a significant influence on a customer's quality perception. Empirical evidence also approved the capability of design factors to affect individual emotion (Bigdeli \& Bigdeli, 2014; Chebat \& Morrin, 2007; Hermawan \& Yusran, 2015), behavioural intention (Ali \& Amin, 2014; Baksi, 2013; Heung \& Gu, 2012), and perceived quality (Jang \& Namkung 2009; Lee \& Kim 2014). Based on previous discussion of literature, the following hypotheses were suggested:

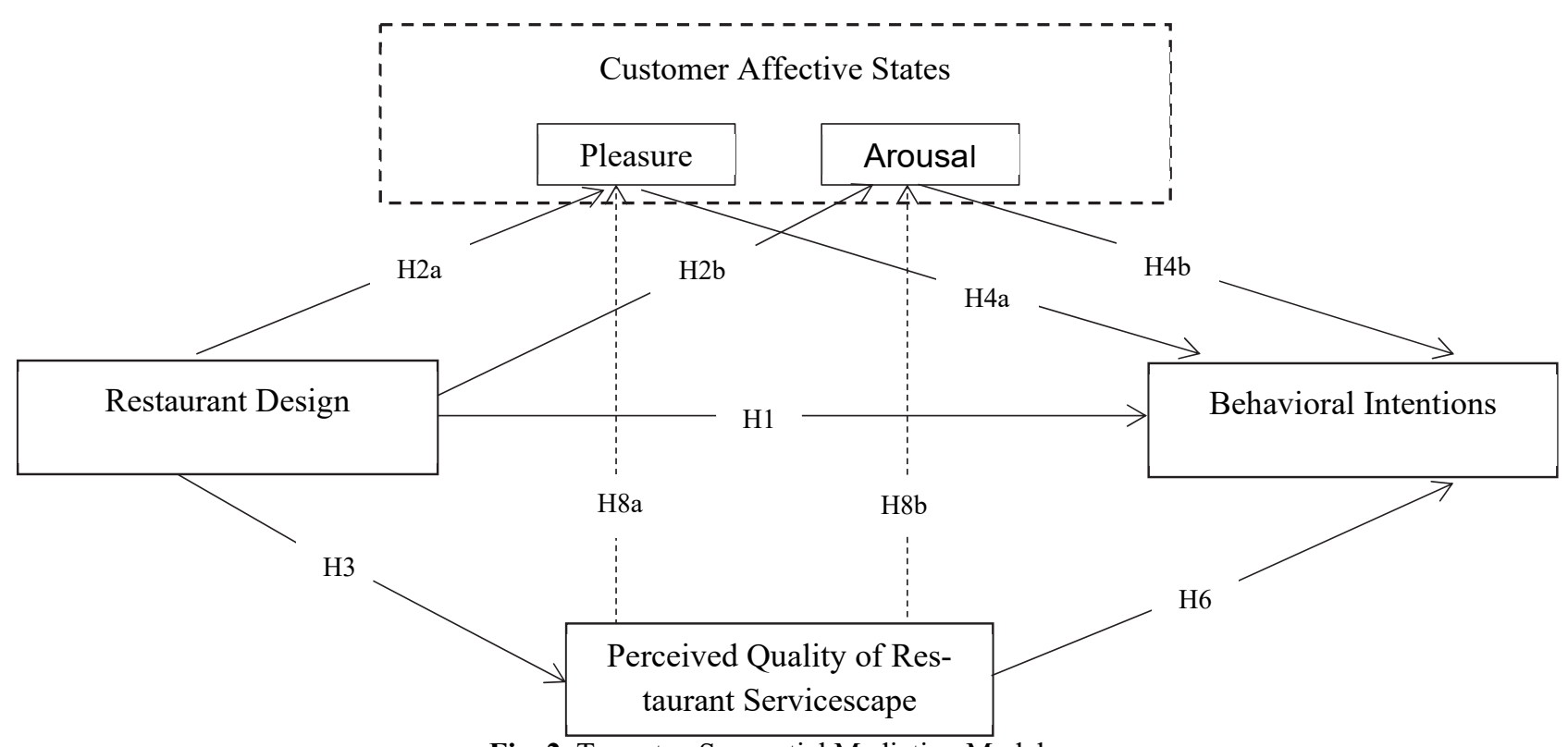

Fig. 2. Two-step Sequential Mediation Model

$\mathbf{H}_{1}$ : There is a significant positive effect of restaurant design on customers' behavioural intentions.

$\mathbf{H}_{2}$ : There is a significant positive effect of restaurant design on customers' affective states of (a) pleasure and (b) arousal.

H3: There is a significant positive effect of restaurant design on the perceived quality of a restaurant servicescape.

Organism represents the internal activities including a set of perceptual, physiological and feeling processes that make up the final action of the individual (Koo \& Ju, 2010). As an organism factor, emotions refer to customer affective senses or feelings in shopping and consumption settings such as shopping malls and restaurants. Whereas, the perceived quality of servicescape is adopted in the current study as an extension to the Mehrabian-Russel's model with an intention to generate a more comprehensive understanding on customer experience while in a servicescape. A servicescape can include two groups of factors, the first group is related to human factors (humanitarian-related factors), this may involve different sorts of customer perceptions such as perceived services provided by restaurant employees, and the second group is related to physical environment features such as design and décor (Khan \& Rahman, 2017). In the M-R model, emotion states fall into three basic elements involving: pleasure; arousal; and dominance (known as PAD states). Conceptual insights and observed evidences reported dominance as a non-significant affective state in predicting individual behaviour in business environments, where much of the affective responses are mainly limited to pleasure and arousal (Ryu \& Jang, 2007; Ali \& Amin, 2014; Bigdeli \& Bigdeli, 2014; Hermawan \& Yusran, 2015; Morrison et al., 2011; and Simanjuntak et al., 2020). In accordance with this, our study will adopt only pleasure and arousal as major affective organism states. The perceived quality of restaurant servicescape is also depicted as another intervening organism factors leading to the final result in the causal chain, which is response. In marketing research, "response" is focused on the final decisions made by consumers (Chang et al., 2011) and is the outcome in the individual approach or avoidance behaviour (Im \& Ha, 2011). Approach behaviours on one hand reflect the positive responses made by the customer on a specific purchasing pattern, whereas the avoidance behaviours include the negative responses that lead to reduce customers' intention to purchase (Eroglu et al., 2001). In light of the previous discussion, the current study utilizes pleasure and arousal to capture individual affective states, while, the perceived quality of restaurant servicescape is measured in terms of customer cognitive evaluation of restaurant servicescape. Customer behavioural intentions are also identified in this research as conative outcomes relating to the positive word of mouth and revisit intentions. Most of previous studies suggested that customer behaviour in restaurant contexts is directly affected by the affective states of customers (Wakefield 
\& Baker, 1998; Hyun \& Kang, 2014; Hermawan \& Yusran, 2015; Park et al., 2019) and their cognitive inferences (Babin et al., 2003; Chen \& Hsieh, 2011, Dedeoglu et al., 2018). Furthermore, such affective states and cognitive evaluations were observed in some cases as mediating variables in the relationship between store environment and customer behaviour (Kim \& Moon, 2009; Lin \& Liang, 2011; Dedeoglu et al., 2018; Park et al., 2019). In this paper, the perceived quality of restaurant servicescape is considered as a cognitive inference made by customers towards the restaurant. Therefore, we predict that:

H4: There is a significant positive effect of customers' affective states of (a) pleasure and (b) arousal in restaurant servicescape on customers' behavioural intentions.

Hs: The relationship between restaurant design and customers' behavioural intentions which is mediated by customers' affective states of (a) pleasure and (b) arousal

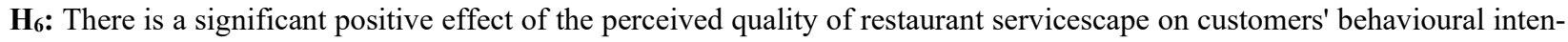
tions.

H7: The relationship between restaurant design and customers' behavioural intentions is mediated by the perceived quality of restaurant servicescape.

Emotion and cognition are identified in the S-O-R model as independent from each other. In this study, we suppose that emotion and cognition as organism factors are interrelated in a way or another. Therefore, the current research departs from this tradition to test a sequential mediating effect between affective states and the perceived quality of servicescape as shown in the proposed model (Fig. 2). Hence, based on Lazarus's (1991) cognitive theory of emotions, whereby customers think first before they feel, the following hypothesis is formulated:

Hs: There is a significant positive effect of the perceived quality of restaurant servicescape on customers' affective states of (a) pleasure and (b) arousal.

H9: The relationship between customers' perceived quality of restaurant servicescape and customers' behavioural intentions which is mediated by their affective states of (a) pleasure and (b) arousal.

\section{Research methodology}

The research population comprises upscale restaurants customers in Jordan. A self-completed questionnaire survey was administered to a convenient sample of 470 restaurant customers, who were intercepted in 7 randomly selected upscale restaurants in Jordan. Nevertheless, respondent selection was randomized, following a systematic sampling procedure to recruit potential respondents, which has largely contributed to reducing selection bias. Furthermore, respondents were asked to fill in the questionnaire while being in the restaurant, so that they can directly experience the restaurant servicescape, thereby, provide more reliable responses. Out of the total number of questionnaires distributed, 425 complete valid responses were generated, indicating (.90) effective response rate. Research variables were observed using Twenty-Six measurement items derived from established empirical research (see Table 1 below). Particularly, restaurant design and customer behavioural intentions were assessed on a 7-point Likert scale, whereas bipolar semantic differential measures were employed to assess customer affective states (pleasure and arousal) and cognitive inferences (the perceived quality of restaurant servicescape).

Table 1

$\underline{\text { Variables and Item Coding }}$

\begin{tabular}{|c|c|c|}
\hline Variables & Items Codes & Sources \\
\hline Restaurant Design & (D1) (D2) (D3) (D4) (D5) (D6) (D7) & $\begin{array}{l}\text { (Ryu \& Jang, 2007) } \\
\text { (Baker et al., 1994) }\end{array}$ \\
\hline Pleasure & (P1) (P2) (P3) (P4) & Mehrabian \& Russell (1974) \\
\hline Arousal & $(\mathrm{A} 1)(\mathrm{A} 2)(\mathrm{A} 3)(\mathrm{A} 4)$ & Mehrabian \& Russell (1974) \\
\hline Perceived Quality of Restaurant Servicescape & (PQR1) (PQR2) (PQR3) (PQR4) (PQR5) (PQR6) & Fisher (1974) \\
\hline Behavioural Intention & (BI1) (BI2) (BI3) (BI4) (BI5) & $\begin{array}{c}\text { Kim \& Moon (2009) } \\
\text { Ryu \& Jang (2007) }\end{array}$ \\
\hline
\end{tabular}

\section{Data analysis and research findings}

As a preliminary procedure, the data was checked for completeness and normality. Descriptive statistics suggested that the data was complete and valid. Also, normality measures including skewness and kurtosis values as suggested by Kline (2005) showed a reasonable normal distribution of the data (skewness $< \pm 3$ and kurtosis $< \pm 10$ ). Descriptive statistics indicate that $(57.8 \%)$ of participants are female and between $36-44$ years old $(58.8 \%)$. The majority of them are Bachelor degree holders (63.0\%), privately employed (60.0\%) with a monthly income level ranges between 1000 JDs to 1499 JDs (25.5\%). Detailed demographic statistics of the observed sample is shown in Table 2 below. The data analysis follows the two-step approach of Anderson and Gerbing (1988), whereby, measurement model validation process is carried out first before the hypothesised structural models are examined. Confirmatory factor analysis (CFA) was conducted to validate the measurement model (typical for both scenarios), followed by reliability and validity assessments. 
Table 2

The summary of personal characteristics of the participants

\begin{tabular}{|c|c|c|c|}
\hline Measure & Item & Count & Percentage $\%$ \\
\hline \multirow[t]{2}{*}{ Gender } & Male & 204 & 48.0 \\
\hline & Female & 246 & 57.8 \\
\hline \multirow{5}{*}{ Age } & $18-26$ & 21 & 04.9 \\
\hline & $27-35$ & 119 & 28.0 \\
\hline & $36-44$ & 250 & 58.8 \\
\hline & $45-53$ & 22 & 05.1 \\
\hline & 54 and above & 13 & 03.2 \\
\hline \multirow{3}{*}{ Marital Status } & Single & 202 & 47.0 \\
\hline & Married & 221 & 50.5 \\
\hline & Other & 2 & 02.5 \\
\hline \multirow{4}{*}{ Education } & Secondary & 45 & 10.5 \\
\hline & Diploma & 34 & 08.0 \\
\hline & Bachelor & 268 & 63.1 \\
\hline & Higher Education & 78 & 18.4 \\
\hline \multirow{3}{*}{ Job } & Public Sector Employee & 44 & 10.4 \\
\hline & Private Sector Employee & 255 & 60.0 \\
\hline & Business Owner & 126 & 29.6 \\
\hline \multirow{5}{*}{ Income } & Less than 500 JDs & 85 & 20.0 \\
\hline & 500-999 JDs & 91 & 21.4 \\
\hline & 1000-1499 JDs & 108 & 25.5 \\
\hline & 1500-1999 JDs & 100 & 23.5 \\
\hline & 2000 JDs and above & 41 & 09.6 \\
\hline
\end{tabular}

Table 3

CFA Analysis Results and Validity and Reliability Measures

\begin{tabular}{|c|c|c|c|c|c|}
\hline Constructs & Indicators & Factor loadings & & $\mathrm{CR}$ & Cronbach's alpha \\
\hline \multirow{7}{*}{ Restaurant Design } & D1 & 0.91 & \multirow{7}{*}{0.80} & \multirow{7}{*}{0.97} & \multirow{7}{*}{0.97} \\
\hline & D2 & 0.90 & & & \\
\hline & D3 & 0.88 & & & \\
\hline & D4 & 0.94 & & & \\
\hline & D5 & 0.89 & & & \\
\hline & D6 & 0.91 & & & \\
\hline & D7 & 0.89 & & & \\
\hline \multirow{4}{*}{ Pleasure } & $\mathrm{P} 1$ & 0.89 & \multirow{4}{*}{0.78} & \multirow{4}{*}{0.94} & \multirow{4}{*}{0.94} \\
\hline & $\mathrm{P} 2$ & 0.87 & & & \\
\hline & P3 & 0.92 & & & \\
\hline & $\mathrm{P} 4$ & 0.86 & & & \\
\hline \multirow{4}{*}{ Arousal } & A1 & 0.86 & \multirow{4}{*}{0.72} & \multirow{4}{*}{0.93} & \multirow{4}{*}{0.92} \\
\hline & $\mathrm{A} 2$ & 0.89 & & & \\
\hline & A3 & 0.89 & & & \\
\hline & A4 & 0.84 & & & \\
\hline \multirow{6}{*}{$\begin{array}{c}\text { Perceived Quality of } \\
\text { Restaurant Servicescape }\end{array}$} & PQR1 & 0.91 & \multirow{6}{*}{0.76} & \multirow{6}{*}{0.96} & \multirow{6}{*}{0.95} \\
\hline & PQR2 & 0.87 & & & \\
\hline & PQR3 & 0.84 & & & \\
\hline & PQR4 & 0.92 & & & \\
\hline & PQR5 & 0.89 & & & \\
\hline & PQR6 & 0.90 & & & \\
\hline \multirow{5}{*}{ Behavioural Intentions } & BI1 & 0.86 & \multirow{5}{*}{0.79} & \multirow{5}{*}{0.95} & \multirow{5}{*}{0.95} \\
\hline & $\mathrm{BI} 2$ & 0.89 & & & \\
\hline & $\mathrm{BI} 3$ & 0.90 & & & \\
\hline & BI4 & 0.92 & & & \\
\hline & BI5 & 0.89 & & & \\
\hline
\end{tabular}

The two competing structural models (one-step vs. two-step mediation models) were compared based on of overall goodness of fit indices (CFI > 0.92; GFI, TLI, NFI, and IFI > 0.90; and RMSEA < 0.08) (Byrne, 2001; Hair et al., 2006). Moreover, structural paths' coefficients were inspected to identify which model exhibits a better practical significance in explaining the effect of restaurant design on customer behavioural intentions. The research measurement model including five latent variables observed by twenty-six measurement items were subjected to Confirmatory Factor Analysis (CFA) using AMOS 21.0. CFA results revealed an excellent model fit for the initial measurement model with $(\chi 2=762, \mathrm{df}=275, \mathrm{p}$ value $=.000, \chi 2 / \mathrm{df}=$ $2.77, \mathrm{CFI}=0.959, \mathrm{NFI}=0.923, \mathrm{TLI}=0.942, \mathrm{IFI}=0.934, \mathrm{RMSEA}=0.057)$. All of the scale items had adequate factor loadings $(>0.50)$ on their latent variables (Hair et al., 2006). Likewise, average variance extracted AVE for all latent variables were above the cut-off point ( $>50 \%$ ) as suggested by Fornell and Larcker (1981). Both Cronbach's alpha reliability and composite reliability scores for all constructs were acceptable (>.70). Accordingly, the convergent validity of the latent constructs is verified. Furthermore, constructs' inter-correlations and the AVE compared to squared correlations between respective constructs were also checked to conclude discriminant validity. Inter-correlation values as presented in Table 4 were acceptable $(<0.85)$ and AVE of each construct was greater than the squared correlations among corresponding constructs as shown in Table 5. Therefore, discriminant validity was also established (Fornell \& Larcker, 1981). In Table 5, diagonal scores are 
squared roots of AVE; off-diagonal values are the values of inter-correlation between the constructs. The two competing structural model were assessed using AMOS-graphics 21.0 with the maximum likelihood as an estimation method. The models consisted of the same latent variables measured by the same observed indicators. However, they represent two different kinds of mediation (e.g. one-step versus two-step sequential mediation). Overall fit indices were inspected to conclude model superiority. Moreover, the practical significance of the models as suggested by path coefficients in each model was also considered in the comparison.

Table 4

Constructs' Inter-correlations

\begin{tabular}{|c|c|c|c|c|c|}
\hline Construct & 1 & 2 & 3 & 4 & 5 \\
\hline 1. Restaurant Design & 1.00 & 0.36 & 0.29 & 0.43 & 0.39 \\
\hline 2. Pleasure & & 1.00 & 0.37 & 0.42 & 0.38 \\
\hline 3. Arousal & & & 1.00 & 0.39 & 0.36 \\
\hline 4. Perceived Quality of Restaurant Servicescape & & & & 1.00 & 0.40 \\
\hline 5. Behavioural Intention & & & & & 1.00 \\
\hline
\end{tabular}

Table 5

Discriminant Validity Test

\begin{tabular}{|c|c|c|c|c|c|}
\hline Construct & 1 & 2 & 3 & 4 & 5 \\
\hline 1. Restaurant Design & 0.80 & 0.13 & 0.08 & 0.18 & 0.15 \\
\hline 2. Pleasure & & 0.78 & 0.14 & 0.18 & 0.14 \\
\hline 3. Arousal & & & 0.72 & 0.15 & 0.13 \\
\hline 4. Perceived Quality of Restaurant Servicescape & & & & 0.76 & 0.16 \\
\hline 5. Behavioural Intention & & & & & 0.79 \\
\hline
\end{tabular}

Table 6

Structural Models' Fit Assessment

\begin{tabular}{ccccccccrr} 
Model & Chi sq & Sig & Df & Chi sq/df & CFI & NFI & TLI & IFI & RMSEA \\
\hline One-step Parallel-mediation & 762 & .000 & 275 & 2.77 & .959 & .923 & .942 & .934 \\
Two-step Cognitive-affective mediation & 745 & .000 & 278 & 2.67 & .959 & .923 & .942 & .935 & .057 \\
\hline
\end{tabular}

As shown in Table 6 a slight better model fit is reported for the two-step cognitive-affective mediated model over the onestep parallel mediation model. Furthermore, path coefficient values suggest that the former model has a greater practical significance and is deemed to be more robust than the latter one in predicting the effect of restaurant design on customer behavioural intentions. The two-step cognitive-affective mediated model is, therefore, used to test the relevant research hypotheses. The findings of hypotheses pertaining the direct relationships among the research variables were reported on the basis of beta coefficient values for relevant paths and their statistical significance as shown in Table 7 . Direct pathshypothesis testing showed a significant positive impact for restaurant design on customer behavioural intention $(\beta=0.29, \mathrm{p}$ $<0.001)$, pleasure $(\beta=0.09, p=.002)$, arousal $(\beta=0.09, p=0.005)$, and perceived quality of restaurant servicescape $(\beta=$ $0.42, \mathrm{p}<0.001)$. Accordingly, a full support was reported for hypotheses one, two, and three. The affective state of pleasure $(\beta=0.25, \mathrm{p}<0.001)$ but not arousal $(\beta=0.05, \mathrm{p}=0.135)$ was found to have a significant positive impact on customer behavioural intention, indicating a partial support for hypothesis four. The findings also support the influence of the perceived quality of restaurant servicescape on customer behavioural intention $(\beta=0.17, \mathrm{p}<0.001)$, customer pleasure $(\beta=$ $0.56, \mathrm{p}<0.001)$ and customer arousal $(\beta=0.45, \mathrm{p}<0.001)$, thus hypothesis six and hypothesis eight were supported.

Table 7

Testing Hypotheses -Direct Relationships

\begin{tabular}{|c|c|c|c|c|c|c|c|}
\hline Hypothesis & & Path & & $(\beta)$ & $\mathrm{p}$ Value & C.R. & Result \\
\hline $\mathrm{H} 1$ & $\mathrm{D}$ & $\rightarrow$ & $\mathrm{BI}$ & .29 & $* * *$ & 8.44 & Confirmed \\
\hline $\mathrm{H} 2 \mathrm{a}$ & D & $\rightarrow$ & $\mathrm{P}$ & .09 & .002 & 3.12 & Confirmed \\
\hline H3 & $\mathrm{D}$ & $\rightarrow$ & PQR & .42 & $* * *$ & 13.468 & Confirmed \\
\hline $\mathrm{H} 4 \mathrm{a}$ & $\mathrm{P}$ & $\rightarrow$ & BI & .25 & $* * *$ & 6.40 & Confirmed \\
\hline H6 & PQR & $\rightarrow$ & $\mathrm{BI}$ & .17 & $* * *$ & 4.06 & Confirmed \\
\hline H8a & PQR & $\rightarrow$ & $\mathrm{P}$ & .56 & $* * *$ & 17.94 & Confirmed \\
\hline
\end{tabular}

$* * *: p<.001,(\beta):$ path coefficient, D: restaurant design PQR: percei
intention. Path in italics suggests an unsupported sub-hypothesis.

Baron and Kenny's (1986) approach was adopted to report the results of mediation hypotheses. Accordingly, the mediation was examined by assessing path coefficients in the model with and without mediators. Mediation type was reported based on the magnitude of direct and mediated effects of the independent variable on the dependent variable. The statistical significance of mediated effects was concluded based on bootstrapping procedures available in AMOS 21.0. The results of indirect paths-hypothesis testing are presented in Table 8. 
Table 8

Test of Mediation

\begin{tabular}{|c|c|c|c|}
\hline Path & $\begin{array}{l}\text { Direct without media- } \\
\text { tor }\end{array}$ & Indirect with mediator & $\begin{array}{c}\text { Indirect effect significance and } \\
\text { Result }\end{array}$ \\
\hline D-P-BI & $.456 *$ & $.304 *$ & Significant (.005) Partial mediation \\
\hline D-A-BI & $.456 *$ & $.306 *$ & Not Significant (.133) No mediation \\
\hline D-PQR-BI & $.456 *$ & $.317 *$ & Significant (.001) Partial mediation \\
\hline PQR-P-BI & $.182 *$ & $.173 *$ & Significant (.001) ) Partial mediation \\
\hline PQR-A-BI & $.182 *$ & $.181 *$ & Not significant (.157) No mediation \\
\hline
\end{tabular}

$*: \mathrm{p}<.001$. D: restaurant design, PQR: perceived quality of restaurant servicescape, P: pleasure, A: arousal, BI: behavioural Intention

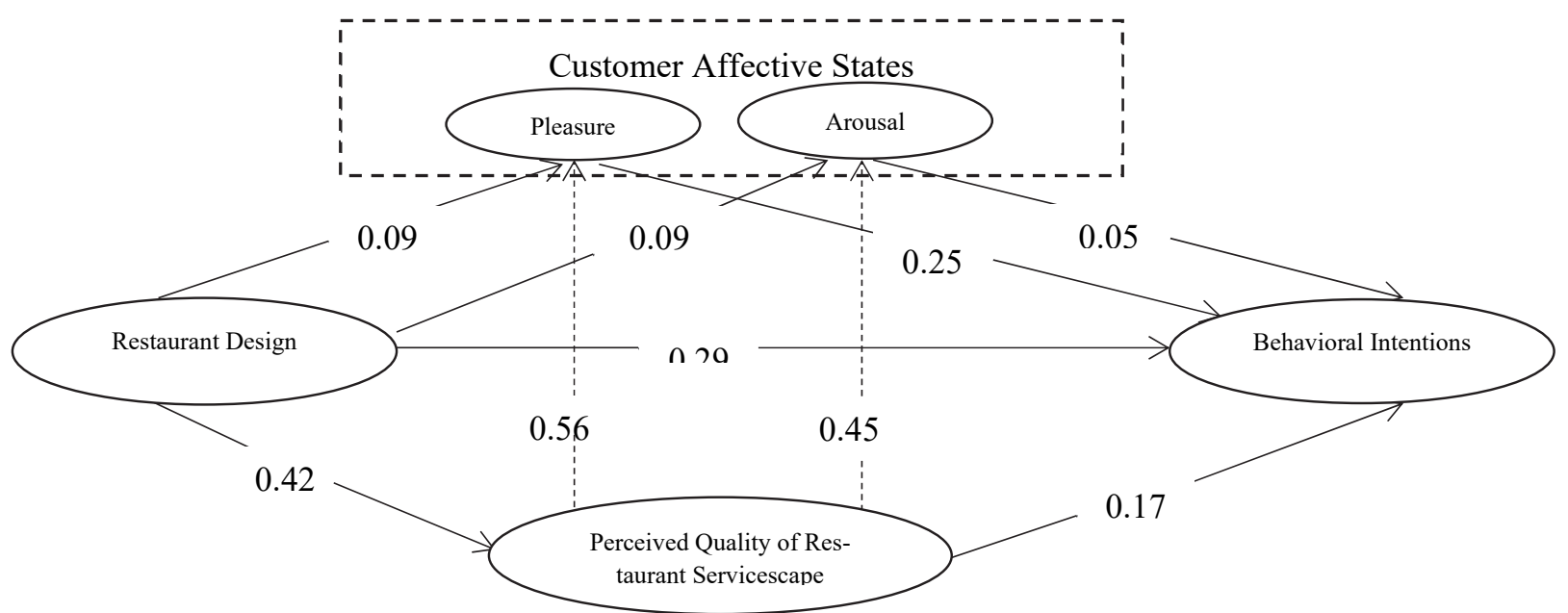

Fig. 3. Two-step Cognition-Emotion Mediation Structural Model

Model Fit: Chi Sq $(\mathrm{df})=745(278) ; \mathrm{Chi} \mathrm{Sq} / \mathrm{df}=2.67 ; \mathrm{CFI}=.959 ; \mathrm{NFI}=.923 ; \mathrm{TLI}=.942 ; \mathrm{IFI}=.935 ; \mathrm{RMSEA}=.056$

Mediation test revealed a partial mediation for the perceived quality of restaurant servicescape along with customer pleasure on restaurant design-customer behavioural intention relationship. These results lend a full support for hypothesis seven and partial support for hypothesis five. In addition, the effect of customers' perceived quality of restaurant servicescape on their behavioural intensions was found to be partially mediated by pleasure but not arousal, indicating a partial support for hypothesis nine.

\section{Discussion of findings}

This research paper is mainly motivated by the objective to examine two competing scenarios of mediation for customer affective states and the perceived quality of restaurant servicescape in the impact of the restaurant design on customer behaviour intentions in Jordan. Assessing models' fit showed that customer restaurant behaviour is better explained by a two-step sequential mediation model than by one-step parallel mediation model. This supports the applicability of Lazarus's (1991) theory of emotions in describing the interplay mediation of emotions and cognition in the S-O-R model. That is, in line with the research outcomes by Lee and Kim (2014) customers use design features in the restaurant environment to develop a set of cognitive inferences (e.g. perceived quality of restaurant servicescape), affecting their emotional states (e.g. pleasure and Arousal), which eventually influence their behaviour intentions. Restaurant design was found to have a significant influence on customer affective states $\left(\mathrm{H}_{2}\right)$, the perceived quality of restaurant servicescape $\left(\mathrm{H}_{3}\right)$ and customer behavioural intentions $\left(\mathrm{H}_{1}\right)$. Previous empirical research revealed supporting findings. For instance, customer behavioural intentions were found to be significantly and directly affected by design factors in different business contexts (Loureiro et al., 2013; Ali \& Amin, 2014; Baksi, 2013; Heung \& Gu, 2012). Restaurant design was also found to enhance the level of customer affective states (Bigdeli \& Bigdeli, 2014; Hyun \& Kang, 2014; Chebat \& Morrin, 2007; Hermawan \& Yusran, 2015) and to improve customers' perceptions in relation to quality (Jang \& Namkung 2009; Lee \& Kim 2014). The results of path analysis suggested that hypothesis four $\left(\mathrm{H}_{4}\right)$ is partially supported. Specifically, the path connecting pleasure of customers to behavioural intentions was confirmed $\left(\mathrm{H}_{4}\right)$. This result indicates that when customers feel higher levels of pleasure, they become more likely to convey higher intentions to revisit the restaurant and to recommend it to their friends. This result conforms to the findings of several similar empirical studies (Ryu \& Jang, 2007; Ali \& Amin, 2014; Bigdeli \& Bigdeli, 2014). The results of Sweeney and Wyber (2002) for instance confirmed a positive association between the affective states of customers and their behavioural intentions. On contrary to what $\left(\mathrm{H}_{4 \mathrm{~b}}\right)$ suggests, no significant impact was noticed for arousal on customer behavioural intentions confirming the findings of some previous empirical studies in this area (Donovan \& Rossiter, 1982; Novak et al., 2010). This may refer to that the effect of arousal on customer behavioural responses may flow indirectly via pleasure as stated in the results of different studies (Hyun \& Kang, 2014; Kaltcheva \& Weitz, 2006; Morrison et al., 2011). That is, customers' arousal, induced by a restaurant's environment improves the level of pleasure they feel, thus, positively affects their behavioural intentions. The findings of mediation analysis indicated that the impact of restaurant design on customer behavioural intentions is partially mediated by customer pleasure $\left(\mathrm{H}_{5 \mathrm{a}}\right)$ and the perceived quality of restaurant servicescape $\left(\mathrm{H}_{7}\right)$. These 
findings are in line with the research results of similar previous empirical studies. For example, the results of Novak et al. (2010) suggest a mediating role for pleasure on the relationship between store ambience and customer behavioural intentions. Similar results were also reported by Vilnai-Yavetz and Gilboa (2010) who addressed the mediating impact of customer pleasure on servicescape's ambience- customer approach behaviour relationship. Likewise, Demoulin (2011) found customer pleasure to mediate the influence of music on the return intentions of customers in restaurant settings. Additionally, other previous research studies revealed supporting findings on the mediation of customer cognitive inferences in the relationship between restaurant environmental cues customer behaviour intentions. For instance, Ryu et al. (2012) demonstrated a significant positive effect for restaurant design characteristics on customer cognitive evaluations such as food value and the quality of service provided, which ultimately lead to certain behavioural intentions. Furthermore, both customer affective states and perceived quality of restaurant servicescape played an interplay mediating role in examining the influence of restaurant design factors on customer behavioural intentions. In particular, perceived quality of restaurant servicescape was found to have a direct impact on each of pleasure and arousal, and indirect influence on the behavioural intentions of customers through pleasure. Thus, a full and partial supports were lent to hypotheses $\left(\mathrm{H}_{8}\right)$ and $\left(\mathrm{H}_{9}\right)$ respectively. This result concurs with the study conducted by Wirtz et al. (2000), which showed a positive impact of customer cognition in the service environment on their affective state, which in turn drives customer behavioural intentions.

\section{Conclusion}

The findings of such study show the significance of restaurant design as a powerful factor in shaping customers' perceptions and driving their behavioural intentions towards upscale restaurants with less significant direct impact on customer emotions. Both customer affective sates and perceived quality of a restaurant's servicescape (evaluation of the restaurant environment) are crucial in predicting customer behaviour in restaurants. Such states play an interactive mediating role, by which, the effect follows a cognitive-affective sequence of mediation. The research's contribution can be discussed by a set of points. Theoretically, the study findings enrich the existing limited empirical evidence on customer behaviour in a restaurant context in developing courtiers, especially in Middle-Eastern countries. Therefore, conducting such a research in Jordan adds to the novelty of this research work. The present research helps to introduce a clearer understanding of the applicability of the traditional S-O-R model and provides extraordinary insights through testing a research model addressing both customer affective states and cognitive inferences as interrelated mediating variables. Moreover, unlike the majority of previous empirical research, the design characteristics were observed in the current study as a multidimensional variable rather than a certain specific aspect such as interior colour, décor, and interior design (Jain et al., 2014; Ryu \& Han, 2011; Tantanatewin \& Inkarojrit, 2018). This provided a broader understanding of several different design features within the restaurant environment and its impact as a holistic unit in enriching customer experience in restaurants. From a practical standpoint, the research findings provided in the present study are instructive for restaurants' operators, trying to understand how the design of their restaurants can be best exploited to enrich customers' experience and to positively influence their behavioural intentions. This is mainly demonstrated by the unique focuses on customer affective and cognitive states and their interplay mediating influence in driving customer behavioural intentions in restaurant contexts.

\section{Limitations and future research}

This study was limited to restaurants in Jordan, where a response from a convenient sample of restaurant customers was used to test the hypothesised models. Such limitation may threaten the generalizability of our findings. This would be avoided by using a more randomly selected sample of participants. Furthermore, since this study focus on understanding the impact of restaurant design on customer behavioural intentions from customer perspective, it would be interesting if such concern is also addressed from a restaurant operators' perspective. Another promising extent of further research is to consider the moderating role of demographic variables to how customers' responses to restaurant design characteristics may vary according to their demographics.

\section{References}

Ali, F., \& Amin, M. (2014). The influence of physical environment on emotions, customer satisfaction and behavioral intentions in Chinese resort hotel industry. Journal for Global Business Advancement, 7(3), 249-266.

Anderson, J. C., \& Gerbing, D. W. (1988). Structural equation modeling in practice: A review and recommended two-step approach. Psychological bulletin, 103(3), 411.

Babin, B. J., Hardesty, D. M., \& Suter, T. A. (2003). Color and shopping intentions: The intervening effect of price fairness and perceived affect. Journal of Business Research, 56(7), 541-551.

Baker, J. (1986). The role of the environment in marketing services: the consumer perspective. Chicago: American Marketing Association.

Baker, J., Grewal, D., \& Parasuraman, A. (1994). The influence of store environment on quality inferences and store image. Journal of the Academy of Marketing Science, 22(4), 328-339.

Baksi, A. (2013). Examining the moderating effects of CRM on retail atmospherics-shopping behavior link. Uncertain Supply Chain Management, 1(3), 115-132.

Baron, R. M., \& Kenny, D. A. (1986). The moderator-mediator variable distinction in social psychological research: Conceptual, strategic, and statistical considerations. Journal of Personality and Social Psychology, 51(6), 1173-1182 
Bigdeli, F., \& Bigdeli, A. (2014). The influence of atmospheric elements on emotions, perceived value and behavioral intentions. Management Science Letters, 4(5), 859-870.

Bitner, M. J. (1992). Servicescapes: The impact of physical surroundings on customers and employees. Journal of marketing, 56(2), 57-71.

Byrne, B. M. (2001). Structural equation modeling with AMOS: Basic concepts, applications, and programming. London: Lawrence Erlbuam Associates

Chang, H. J., Eckman, M., \& Yan, R. N. (2011). Application of the Stimulus-Organism-Response model to the retail environment: the role of hedonic motivation in impulse buying behaviour. The International Review of Retail, Distribution and Consumer Research, 21(3), 233-249.

Chang, H. J., Yan, R.-N., \& Eckman, M. (2014). Moderating effects of situational characteristics on impulse buying. International Journal of Retail \& Distribution Management, 42(4), 298-314.

Chebat, J. C., \& Michon, R. (2003). Impact of ambient odors on mall shoppers' emotions, cognition, and spending: A test of competitive causal theories. Journal of Business Research, 56(7), 529-539.

Chebat, J. C., \& Morrin, M. (2007). Colors and cultures: Exploring the effects of mall décor on consumer perceptions. Journal of Business Research, 60(3), 189-196.

Chen, H., \& Hsieh, T. (2011). The effect of atmosphere on customer perceptions and customer behavior responses in chain store supermarkets. African Journal of Business Management, 5(24), 10054-10066.

De Nisco, A., \& Warnaby, G. (2013). Shopping in downtown: The effect of urban environment on service quality perception and behavioral intentions. International Journal of Retail \& Distribution Management, 41(9), 654-670.

Dedeoglu, B. B., Bilgihan, A., Ye, B. H., Buonincontri, P., \& Okumus, F. (2018). The impact of servicescape on hedonic value and behavioral intentions: The importance of previous experience. International Journal of Hospitality Management, 72, 10-20.

Demoulin, N. T. (2011). Music congruency in a service setting: The mediating role of emotional and cognitive responses. Journal of Retailing and Consumer Services, 18(1), 10-18.

Dennis, C., Michon, R., Brakus, J. J., Newman, A., \& Alamanos, E. (2012). New insights into the impact of digital signage as a retail atmospheric tool. Journal of consumer Behavior, 11(6), 454-466.

Donovan, R. J., \& Rossiter, J. R. (1982). Store atmosphere: an environmental psychology approach. Journal of Retailing, 58(1), 34-57.

Donovan, R. J., Rossiter, J. R., Marcoolyn, G., \& Nesdale, A. (1994). Store atmosphere and purchasing behavior. Journal of retailing, 70(3), 283-294.

Eroglu, S. A., Machleit, K. A., \& Davis, L. M. (2001). Atmospheric qualities of online retailing: A conceptual model and implications. Journal of Business research, 54(2), 177-184.

Fisher, J. D. (1974). Situation-specific variables as determinants of perceived environmental aesthetic quality and perceived crowdedness. Journal of Research in Personality, 8(2), 177-188.

Fornell, C., \& Larcker, D. F. (1981). Structural equation models with unobservable variables and measurement error: Algebra and statistics.

Githiri, M. N. (2016). Influence of physical environment on customer satisfaction and return intention in Kenyan rated restaurants. Asian Journal of Social Science Studies, 2(1), 11.

Hair, J. F., Anderson, R. E., Tatham, R. L., \& Black, W. C. (2006). Multivariate Data Analysis (6 ${ }^{\text {th }}$ ed.). Upper Saddle River, New Jersey: Pearson-Prentice Hall.

Hair, J. F., Celsi, M. W., Money, A. H., Samouel, P., \& Page, M. J. (2011). Essentials of business research methods (2 ed.). New York: M. E. Sharpe.

Hermawan, A., \& Yusran, H. L. (2015). The effects of dental atmospherics on patient's emotion and behavioral intentions. Economic Review, 44(1), 44-52.

Heung, V. C., \& Gu, T. (2012). Influence of restaurant atmospherics on patron satisfaction and behavioural intentions. International Journal of Hospitality Management, 31(4), 1167-1177.

Hyun, S. S., \& Kang, J. (2014). A better investment in luxury restaurants: Environmental or non-environmental cues? International Journal of Hospitality Management, 39, 57-70.

Im, H., \& Ha, S. (2011). An exploration of the cognitive-affective model of satisfaction in a shopping context: A test of competing models. The Service Industries Journal, 31(13), 2273-2288.

Jain, V., Takayanagi, M., Malthouse, E. C., \& Biswas, D. (2014). Effects of Show Windows on Female Consumers' Shopping Behavior. Journal of Consumer Marketing, 31(5).

Jang, S. C. S., \& Namkung, Y. (2009). Perceived quality, emotions, and behavioral intentions: Application of an extended Mehrabian-Russell model to restaurants. Journal of Business Research, 62(4), 451-460.

Kalra, A., Richardson-Greenfield, P., Han, M., \& Sun, S. (2016). Disgust and Music: Can Retail Environment Buffer the Emotion of Disgust?. 2016 SMA Proceedings, 251.

Kaltcheva, V., \& Weitz, B. A. (2006). The moderating influence of motivational orientation on the relationship between shopping environment arousal and behavior. Journal of Marketing, 70(1), 107-118.

Khan, I., \& Rahman, Z. (2017). Development of a scale to measure hotel brand experiences. International Journal of Contemporary Hospitality Management, 29(1), 268-287.

Kim, W. G., \& Moon, Y. J. (2009). Customers' cognitive, emotional, and actionable response to the servicescape: A test of the moderating effect of the restaurant type. International Journal of Hospitality Management, 28(1), 144-156. 
Kivela, J., Inbakaran, R., \& Reece, J. (1999). Consumer research in the restaurant environment, Part 1: A conceptual model of dining satisfaction and return patronage. International Journal of Contemporary Hospitality Management, 11(5), 205222.

Koo, D. M., \& Ju, S. H. (2010). The interactional effects of atmospherics and perceptual curiosity on emotions and online shopping intention. Computers in Human Behavior, 26(3), 377-388.

Kumar, A., \& Kim, Y.-K. (2014). The store-as-a-brand strategy: The effect of store environment on customer responses. Journal of Retailing and Consumer Services, 21(5), 685-695.

Lazarus, R. S. (1991). Emotion and adaptation. Oxford University Press, USA.

Lee, S. Y., \& Kim, J. H. (2014). Effects of servicescape on perceived service quality, satisfaction and behavioral outcomes in public service facilities. Journal of Asian Architecture and Building Engineering, 13(1), 125-131.

Lin, J. S. C., \& Liang, H. Y. (2011). The influence of service environments on customer emotion and service outcomes. Managing Service Quality, 21(4), 350-372.

Loureiro, S. M. C., Koo, D.-M., \& Ribeiro, L. (2013). Effects of atmospherics on emotions and intention with respect to involvement in different shopping environments. Journal of Global Scholars of Marketing Science, 23(4), 435-459.

Martín-Ruiz, D., Barroso-Castro, C., \& Rosa-Díaz, I. M. (2012). Creating customer value through service experiences: an empirical study in the hotel industry. Tourism and Hospitality Management, 18(1), 37-53.

Mehrabian, A., \& Russell, J. A. (1974). An Approach to Environmental Psychology. Cambridge: MIT Press.

Meng, B., \& Choi, K. (2017). Theme restaurants' servicescape in developing quality of life: The moderating effect of perceived authenticity. International Journal of Hospitality Management, 65, 89-99.

Morrison, M., Gan, S., Dubelaar, C., \& Oppewal, H. (2011). In-store music and aroma influences on shopper behavior and satisfaction. Journal of Business Research, 64(6), 558-564.

Novak, C. C., La Lopa, J., \& Novak, R. E. (2010). Effects of sound pressure levels and sensitivity to noise on mood and behavioral intent in a controlled fine dining restaurant environment. Journal of Culinary Science \& Technology, 8(4), 191218.

Nusairat, N. M., Akhorshaideh, A. H. O., Rashid, T., Sahadev, S., \& Rembielak, G. (2017). Social cues-customer behavior relationship: the mediating role of emotions and cognition. International Journal of Marketing Studies, 9(1), 1-17.

Ortegón-Cortázar, L., \& Royo-Vela, M. (2019). Effects of the biophilic atmosphere on intention to visit: the affective states' mediating role. Journal of Services Marketing.

Park, J. Y., Back, R. M., Bufquin, D., \& Shapoval, V. (2019). Servicescape, positive affect, satisfaction and behavioral intentions: The moderating role of familiarity. International Journal of Hospitality Management, 78, 102-111.

Ryu, K., \& Han, H. (2011). New or repeat customers: how does physical environment influence their restaurant experience?. International Journal of Hospitality Management, 30(3), 599-611.

Ryu, K., \& Jang, S. C. S. (2007). The effect of environmental perceptions on behavioral intentions through emotions: The case of upscale restaurants. Journal of Hospitality \& Tourism Research, 31(1), 56-72.

Ryu, K., Lee, H. R., \& Gon Kim, W. (2012). The influence of the quality of the physical environment, food, and service on restaurant image, customer perceived value, customer satisfaction, and behavioral intentions. International Journal of Contemporary Hospitality management, 24(2), 200-223.

Simanjuntak, M., Nur, H., Sartono, B., \& Sabri, M. (2020). A general structural equation model of the emotions and repurchase intention in modern retail. Management Science Letters, 10(4), 801-814.

Sweeney, J. C., \& Wyber, F. (2002). The role of cognitions and emotions in the music-approach-avoidance behavior relationship. Journal of Services Marketing, 16(1), 51-69.

Tantanatewin, W., \& Inkarojrit, V. (2018). The influence of emotional response to interior color on restaurant entry decision. International Journal of Hospitality Management, 69, 124-131.

Vieira, V. A. (2013). Stimuli-organism-response framework: A meta-analytic review in the store environment. Journal of Business Research, 66(9), 1420-1426.

Vilnai-Yavetz, I., \& Gilboa, S. (2010). The effect of servicescape cleanliness on customer reactions -New. Services Marketing Quarterly, 31(2), 213-234.

Wakefield, K. L., \& Baker, J. (1998). Excitement at the mall: determinants and effects on shopping response. Journal of Retailing, 74(4), 515-539.

Wakefield, K. L., \& Blodgett, J. G. (1996). The effect of the servicescape on customers' behavioral intentions in leisure service settings. Journal of Services Marketing, 10(6), 45-61.

Wirtz, J., Mattila, A. S., \& Tan, R. L. (2000). The moderating role of target-arousal on the impact of affect on satisfactionan examination in the context of service experiences. Journal of retailing, 76(3), 347-365.

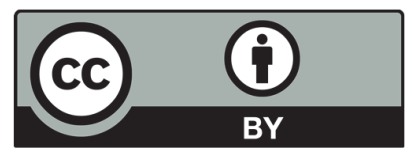

(C) 2020 by the authors; licensee Growing Science, Canada. This is an open access article distributed under the terms and conditions of the Creative Commons Attribution (CC-BY) license (http://creativecommons.org/licenses/by/4.0/). 